\title{
Corrigendum: Persistent signaling induced by FTY720-phosphate is mediated by internalized S1P1 receptors
}

Florian Mullershausen, Frédéric Zecri, Cihan Cetin, Andreas Billich, Danilo Guerini \& Klaus Seuwen

Nat. Chem. Biol. 5, 428-434 (2009); published online 10 May 2009; corrected after print 13 November 2009

In the version of this article initially published, the chemical structures in Fig. 2a and in the graphical abstract were incorrect. The error has been corrected in the HTML and PDF versions of the article.

\section{Erratum: S1P1 signaling just keeps going and going and going...}

Stuart Cahalan \& Hugh Rosen

Nat. Chem. Biol. 5, 377-378 (2009); published online 15 May 2009; corrected after print 13 November 2009

In the version of this article initially published, the chemical structures for AFD-R, FTY720-P and OC5 were incorrect. The error has been corrected in the HTML and PDF versions of the article.

\section{Erratum: Targeting proteins for degradation}

Erin K Schrader, Kristine G Harstad \& Andreas Matouschek

Nat. Chem. Biol. 5, 815-822 (2009); published online 19 October 2009; corrected after print 28 October 2009

In the version of this article initially published, a positive competing financial interest statement was noted, where none exists. The error has been corrected in the HTML and PDF versions of the article.

\section{Erratum: The role of dynamic conformational ensembles in biomolecular} recognition

David D Boehr, Ruth Nussinov \& Peter E Wright

Nat. Chem. Biol. 5, 789-796 (2009); published online 19 October 2009; corrected after print 28 October 2009

In the version of this article initially published, in Figure 3 the term "free energy" appears with the horizontal axes rather than the vertical axes of the energy diagrams. The error has been corrected in the HTML and PDF versions of the article. 